\title{
An Approach Study for Reducing the Early Embryonic Loss in Egyptian Buffalo-cows
}

\author{
Mohamed Abd El-Fattah Abo-Farw", Osama Mostafa Elmalky, Emad Fawzy Elmaghraby, \\ Hassab Allah Abdul Gwad Abu Elghait, Maged Ahmed Aboul-Omran
}

Animal Production Research Institute, Agricultural Research Center, Giza, Egypt

Email address:

abofarwmohamed@yahoo.com (M. A. El-Fattah Abo-Farw)

${ }^{*}$ Corresponding author

\section{To cite this article:}

Mohamed Abd El-Fattah Abo-Farw, Osama Mostafa Elmalky, Emad Fawzy Elmaghraby, Hassab Allah Abdul Gwad Abu Elghait, Maged Ahmed Aboul-Omran. An Approach Study for Reducing the Early Embryonic Loss in Egyptian Buffalo-cows. Advances in Applied Physiology. Vol. 5, No. 2, 2020, pp. 48-57. doi: 10.11648/j.aap.20200502.17

Received: October 28, 2020; Accepted: November 13, 2020; Published: November 30, 2020

\begin{abstract}
This study evaluated the efficacy of a single gonadotropin-releasing hormone (GnRH) agonist on day 12 or human chorionic gonadotropin ( $\mathrm{hCG}$ ) on day 7 post-mating on pregnancy rate (PR) of repeat breeder buffaloes. Buffaloes $(\mathrm{n}=21)$ in heat were naturally mated, and divided into three groups ( $7 \mathrm{in} \mathrm{each).} \mathrm{Animals} \mathrm{in} \mathrm{the} 1^{\text {st }}$ group (G1) were i.m. injected with $5 \mathrm{ml}$ $\mathrm{GnRH}$ on 12-day post-mating, while those in G2 were i.m. injected with $1500 \mathrm{IU}$ of hCG on day 7 post-mating. In G3, animals were kept as control. Results show that PR was higher $(\mathrm{P}<0.05)$ in G1 (71.428) and G2 (57.142) than G3 (28.571). The peak of serum $\mathrm{P} 4$ was recorded $(\mathrm{P}<0.05)$ on day 15 in $\mathrm{G} 2$, and day 18 in $\mathrm{G} 1$ and $\mathrm{G} 3$. On days 21 and 24 post-mating, $\mathrm{P} 4$ was the highest $(\mathrm{P}<0.05)$ in $\mathrm{G} 1$, followed by G2, and the lowest in G3. Average CL diameter increased $(\mathrm{P}<0.05)$ CL in G1 and G2 compared with G3 on days 15 and 18 post-mating. The concentration of P4 was higher in pregnant than in non-pregnant animals on different post-mating days, regardless of treatment. The concentration of P4 was the highest in pregnant of G2, and the lowest in non-pregnants of G3, being more obvious from 18 to 24-day post-mating. Injection of repeat breeder lactating buffaloes with $5 \mathrm{ml}$ GnRH or 1500 IU hCG on day 12 and 7 post-mating, respectively, improved P4 production and pregnancy rate. GnRH treatment reduced the early embryonic loss showing the highest pregnancy rate to increase the farmer economy.
\end{abstract}

Keywords: Buffaloes, Repeat Breeder, GnRH, hCG, Estrous, Pregnancy, Progesterone, CL Diameter

\section{Introduction}

The reproductive efficiency is affected by very wellknown factors like fertilization failure and embryonic mortality, the later being more significant of dairy cattle and buffaloes [8]. Embryonic mortality denotes the death of fertilized ova and embryos up to the end of implantation [26]. In buffalo species, embryonic mortality is considered one of the major causes of fertility loss, especially in the animals that are not mated during their reproductive period [12]. The percentage of insemination in cattle is about $90-100 \%$, and only $70 \%$ of all pregnancies end with giving birth to live fetuses. The other $30 \%$ of pregnancies are interrupted because of some type of embryonic loss (EL); in $65 \%$ of these cases, the embryonic death occurred between the 6 th and 18th days of gestation in animals [17].
Early embryonic mortality is one of a major economic loss to dairy producers. Approximately $25 \%$ [50] or $40 \%$ [7] of bovine embryos are lost in the first 3 weeks of life of which the greatest proportion seems to occur between 14 and 17 days after ovulation [67]. A major contributing factor of early embryonic death in cattle is believed to be due to low progesterone (P4) production by the corpus luteum, CL [46]. Embryonic development is related to concentrations of P4 and the ability of the conceptus to secrete the antiluteolytic hormone, interferon-t [38]. Early embryonic mortality increased cost of artificial insemination [66, 77, 7], extended calving intervals and prolonged dry period resulting in reduced lifetime milk production [58] and reduced net calf crop [41]. In large animals, major of EL occurs in the preimplantation stage (20 days of pregnancy), when $75-80 \%$ of fertilized eggs are lost [66]. One of the causes of EL is thought to be the inadequate luteal function [74]. 
Blood P4 profile is indicator of EL at the time of CL maintenance causing delaying the lutolysis and prolongation of the interval between estrus cases [25], and CL regression is delayed if EL preceded the luteolysis. Non-return rate to estrus is depending on the follicular development, if luteolysis preceded and probabl EL occur [28]. Therefore, early EL is attributed to luteolysis and return to estrus 24 day post-mating, while return to estrus is delayed more than 24 day (late EL) with CL maintenance [25].

The progesterone hormone plays an important role in the implantation of the embryo into the uterine wall, but luteal dysfunction leads to inadequate production of P4 after breeding which causes early embryonic death [27]. Exposure to an insufficient circulating level of $\mathrm{P} 4$ during the growth of the ovulatory follicle is one of the important factors that affect fertility in high producing animals. P4 has a negative feedback effect on LH secretion and it is believed that subluteal phase plasma P4 concentrations result in elevated $\mathrm{LH}$ pulse-frequency [20]. It has previously been suggested that low progesterone during early embryonic development may cause pregnancy failure and thereby reduce the pregnancy rate [33]. Luteal deficiency during the first 3 weeks of pregnancy has been hypothesized as a cause of pregnancy failure [37, 61]. Various studies have demonstrated a favourable effect of $\mathrm{P} 4$ during dominant follicle development on subsequent CL development, CL functionality and fertility in cattle $[32,75,15]$.

Various hormonal treatments have been used in attempts to reduce embryonic loss to improve pregnancy rates in bovine and buffaloes. Administration of GnRH or hCG at the time of insemination favours LH surge, which results in improved pregnancy rate [40]. Other studies showed that administration of natural sequence GnRH agonists or hCG after AI can stimulate CL function, induce accessory CL formation, increases $\mathrm{P} 4$, and reduces estradiol production, with a consequent positive effect on embryonic survival [9]. In buffaloes treatment with buserelin, hCG and P4, on day 5 after AI, increases P4 on Day 15, but did not reduce the incidence of embryonic mortality [11]. However, response to such therapy differed in different animals [52, 64]. [76] supported the use of $\mathrm{GnRH}$ on day 12 post-mating as a method for enhancing pregnancy rates in lactating dairy cattle. The stage at which GnRH is given in the luteal phase has been varied between days 11 and 13 after insemination improvement with variable results. The remarkable improvement in pregnancy rate was found mostly in the treatment between days 11 and 13 after insemination in cattle [51] and buffaloes [2, 1]. Effects of GnRH and hCG on pregnancy rates are inconsistent, some researchers have reported increased conception rate in lactating dairy cattle [4], whereas, others have reported no effect [60].

According to some reports, the presence of an early P4 peak (within 5 days after mating or AI) facilitates the elongation of the conceptus $[68,39]$. It has been demonstrated that an early P4 peak reduces embryonic mortality in cows [39]. In cattle, repeat breeding condition could be therapy by GnRH and hCG treatments to improve their reproductive efficiency and thereby the farmers economy [48]. Therefore, the present study suggests the efficacy of a single administration of GnRH agonist on day 12 or hCG on day 7 of mating on conception rate of repeat breeder buffalo cows.

\section{Materials and Methods}

Animals were maintained at Animal Production Experimental Station, Mehallet Moussa, Kaferelsheikh Governorate, Animal Production Research Institute (APRI), Agricultural Research Center, Ministry of Agriculture during the period from May to September 2019.

\subsection{Animals and Management}

The experimental work of this study was carried out on 21 cyclic lactating Egyptian buffalo cows healthy (4-7 years old and 470-510 kg live body weight) with more than 90 days postpartum after normal calving and failed to conceive after more than 3 services/animal with fertile semen. During postpartum, all buffalo cows used in this study showed a normal oestrous cycle and had no clinical illness signs. The examination of the reproductive tract of all buffaloes by rectal palpation and ultrasonography revealed pathologically intact genital tract of all animals. Throughout the experimental period, animals were maintained under the similar feeding and managerial systems adopted by APRI. Animals were housed under semi-open sheds and freshwater was available all day time.

\subsection{Experimental Design}

The experimental buffalo cows $(n=21)$ were divided into three experimental groups ( 7 animals in each). Animals in all groups were mated when they were in estrus. Then animals in the $1^{\text {st }}$ group were i.m. injected with $5 \mathrm{ml}$ synthetic $\mathrm{GnRH}$ agonist (Buserelin acetate- Receptal, Intervet) on 12-day post-mating (G1), while those in the $2^{\text {nd }}$ group (G2) were i.m. injected with 1500 IU of human chorionic gonadotropin (hCG, Pregnyl, Intervet) on day 7 of mating. In the $3^{\text {rd }}$ group, animals were without any hormonal therapy and kept as control (G3).

\subsection{Reproductive Management}

Estrus was visually detected between 8 a.m and 7 p.m. using an infertile teaser present with buffaloes all times. Buffalo-cows in heat were naturally mated by fertile buffalo bull of known high fertility.

Early pregnancy diagnosis was done 24-day post-mating for each animal using ultrasound examination (Digital ultrasonic diagnostic imaging System, Model Dp-30 Vet. 50/60 HZ, SHENZHEN, MINDRAY BIO-MEDICAL. ELECTRONICS, CO. LTD) $7.5 \mathrm{MHz}$ Linear array transducer and Depth 4.3.

Pregnancy was indicated by rectal palpation of nonreturned animals on day 45-55 post-mating. Then pregnancy rate was calculated based on the number of conceived 
animals relative to mated animals.

\subsection{Corpus Luteum Measurement}

Presence and average diameter of the CL was determined using ultrasound examination on days 9,15 and 18 postmating.

\subsection{Blood Samples and Progesterone Assay}

Blood samples were collected from the jugular vein of all animals in each group on days 0 (estrus), 6, 9, 12, 15, 18, 21 and 24 post-mating. Blood samples were collected into sterilized glass tubes and kept at room temperature. Within an hour after collection, samples were centrifuged at $3000 \mathrm{rpm}$ for $15 \mathrm{~min}$, then serum was separated and transferred into sterilized vials stored at $-20^{\circ} \mathrm{C}$ until $\mathrm{P} 4$ assay.

Direct Radioimmunoassay technique (RIA) was performed for determination of serum P4 concentration using ready antibody-coated tubes kit (Diagnosis Systems Laboratories Texas, USA) according to the procedure outlined by the manufacturer.

\subsection{Statistical Analysis}

Data of P4 concentration and average CL diameter were subjected to ANOVA one-way design to study the effect of treatment (differences among groups) at each sampling time. Data of pregnancy rates were analyzed to study the effect of treatment by Chi-square test. However, the differences between pregnant and non-pregnant animals for all animals or within each group were tested using student T-test.

All data were statistically analyzed using SAS (2004) program. However, the differences among groups were set at $\mathrm{P}<0.05$ using Duncan Multiple Range Test [18].

\section{Results and Discussion}

\subsection{Pregnancy Rate}

The pregnancy rate $(\mathrm{PR})$ was significantly $(\mathrm{P}<0.05)$ increased in treatment groups (G1 and G2) as compared to G3 (control), but the differences in PR between G1 and G2 or G2 and G3 were not significant (Table 1). These results indicated a positive effect of hormonal treatment, in particular, GnRH injection 12 days post-mating on PR buffalo cows.

Table 1. Pregnancy rate of buffalo cows in different experimental groups.

\begin{tabular}{llll}
\hline $\begin{array}{l}\text { Experimental } \\
\text { group }\end{array}$ & $\begin{array}{l}\text { Number of } \\
\text { mated animals }\end{array}$ & $\begin{array}{l}\text { Number of conceived } \\
\text { animals }\end{array}$ & $\begin{array}{l}\text { Pregnancy } \\
\text { rate }\end{array}$ \\
\hline G1 $(\mathrm{GnRH})$ & 7 & 5 & $71.428^{\mathrm{a}}$ \\
G2 (hCG) & 7 & 4 & $57.142^{\mathrm{ab}}$ \\
G3 (control) & 7 & 2 & $28.571^{\mathrm{b}}$ \\
\hline
\end{tabular}

Means denoted within the same column with different superscripts are significantly different at $\mathrm{P}<0.05$.

The obtained highest PR in G1 treated with GnRH $(71.43 \%)$ is in near agreement with PR of $73.3 \%$ in repeat breeding dairy cattle [63]. In accordance with this improvement in $\mathrm{PR}$, treatment with GnRH $(10.5 \mu \mathrm{g})$ on day 12 post-mating increased PR from $50 \%$ in the control group to $77.7 \%$ in treated cows [76]. Also, PR following the treatment with GnRH on 11-12 days post-mating have been demonstrated to be increased as reported by several authors $[53,51]$. However, higher PR $(83.3,75$ and $73.6 \%)$ than that obtained in our study was reported by [49] in RB cows, [44] in RB Deoni cows, and [59] in bovine, respectively. comparatively lower PR of $32.0 \%$ [43] and $12.50 \%$ [40] were reported on repeat breeder cows, or 36.3 [31] and 44.3\% [21] in dairy cows. On the other hand, some investigators found a non-significant effect of $\mathrm{GnRH}$ on conception rate in dairy cows $[71,70]$. Administration of $\mathrm{GnRH}$ or its analogue to cattle alters the function of corpus luteum (CL) and follicular dynamics by enhancing acute secretion followed by a rise in circulating LH and FSH [71]. Inconsistent effect of GnRH on the conception rate among different studies might be attributed to either potency of GnRH on gonadotropin release or the time of GnRH treatment [42]. Moreover, administration of GnRH on day 23 enhanced the herd fertility by reducing embryonic losses in lactating Nili-Ravi buffaloes [6]. Incomparable with the results of PR in G2 treated with hCG $(57.1 \%)$, similar value $(58 \%)$ was reported by [30] in crossbred cows. [31, 40] found conception rates of 45.45 and $50.00 \%$ in repeat breeding cattle. Also, injection of hCG increased conception rates of cows on days 28 (45.8 vs. $38.7 \%$ ), 45 (40.4 vs. $36.3 \%$ ) and 90 (38.4 vs. $31.9 \%)$ compared to saline injection [62]. hCG has been used with variable success to improve PR in cattle [32].

The present results concerning the PR obtained in our study of the control group indicate an improvement in PR by about 150 and $100 \%$ following administration of repeat breeder buffalo-cows by GnRH and hCG, respectively. This increase in PR in GnRH and hCG treated RB buffalo cows is economically important in Egypt.

\subsection{Serum P4 Profile on Different Post-mating Days}

Results of $\mathrm{P} 4$ profile on different post-mating days indicated insignificant differences in P4 concentration among the experimental groups on day 0 and 6 post-mating because on these days animals in all groups were without any treatment. On day 9 post-mating, there was a significant difference in P4 concentration, being significantly $(\mathrm{P}<0.05)$ higher in $\mathrm{G} 2$ than in G1 and G3 as a result of treatment of buffalo cows in G2 with hCG on day 7 post-mating versus untreated animals in G1 and G3. On day 15 post-mating, $\mathrm{P} 4$ level significantly $(\mathrm{P}<0.05)$ increased in G1 and G2 as compared to G3, but P4 level reached the maximum concentration in $\mathrm{G} 2$, being significantly higher than in G1. Increasing P4 concentration in G1 in comparing with G3 was undergoing the treatment of animals in this group on day 12 post-mating. On the following postmating days (18, 21 and $24 \mathrm{~d}), \mathrm{P} 4$ concentration was significantly $(\mathrm{P}<0.05)$ the highest in $\mathrm{G} 1$, followed by $\mathrm{G} 2$, and the lowest in G3 (Table 2).

These findings indicated a positive impact following the hormonal therapies on improving P4 level during the early post-mating period for pregnancy maintenance. The observed 
improvement in P4 profile in G1 and G2 during post-mating days is in association with increasing PR of treatment groups compared with the control animals, being the highest in animals treated with GnRH on day 12 .

Table 2. Concentration of serum progesterone of buffalo cows in the experimental groups on different post-mating days.

\begin{tabular}{|c|c|c|c|c|}
\hline \multirow{2}{*}{$\begin{array}{l}\text { Post- } \\
\text { mating day }\end{array}$} & \multicolumn{3}{|c|}{ Serum progesterone $(\mathrm{ng} / \mathrm{ml})$} & \multirow{2}{*}{ P-value } \\
\hline & G1 (GnRH) & G2 (hCG) & G3 (Control) & \\
\hline 0 & $0.370 \pm 0.033$ & $0.384 \pm 0.026$ & $0.323 \pm 0.046$ & $0.375^{\mathrm{NS}}$ \\
\hline 6 & $1.356 \pm 0.087$ & $1.285 \pm 0.079$ & $1.393 \pm 0.105$ & $0.796^{\mathrm{NS}}$ \\
\hline 9 & $2.175 \pm 0.135^{\mathrm{b}}$ & $3.028 \pm 0.235^{\mathrm{a}}$ & $2.150 \pm 0.186^{\mathrm{b}}$ & $0.0041^{* *}$ \\
\hline 15 & $3.668 \pm 0.242^{\mathrm{b}}$ & $4.471 \pm 0.425^{\mathrm{a}}$ & $2.750 \pm 0.345^{\mathrm{c}}$ & $0.0031^{* *}$ \\
\hline 18 & $4.943 \pm 0.386^{\mathrm{a}}$ & $4.014 \pm 0.445^{\mathrm{b}}$ & $2.881 \pm 0.269^{c}$ & $0.0008^{* * *}$ \\
\hline 21 & $4.006 \pm 0.703^{\mathrm{a}}$ & $3.242 \pm 0.706^{\mathrm{b}}$ & $2.378 \pm 1.188^{c}$ & $0.0001^{* * *}$ \\
\hline 24 & $4.156 \pm 1.036^{\mathrm{a}}$ & $2.942 \pm 0.878^{b}$ & $1.843 \pm 0.600^{\mathrm{c}}$ & $0.0002^{* * *}$ \\
\hline
\end{tabular}

Concerning the change in P4 level during different postmating days, results illustrated in Figure 1 cleared similar trend of change in P4 level in all experimental groups, whereas P4 increased following estrus/mating to reach the maximum value earlier in G2 on day 15 than in G1 and G3 on day 18. Thereafter, P4 level showed a gradual reduction up to day 24 post-mating in all groups, being the highest in $\mathrm{G} 1$, followed by G2, and the lowest in G3 (control).

The earlier P4 peak of animals in G2 versus the control group may be due to the positive effect of early treatment with hCG on development of CL in this group, but values of $\mathrm{P} 4$ peak still to be higher in G2 than in G3, but lower in G2 than that in G1 (Figure 1).

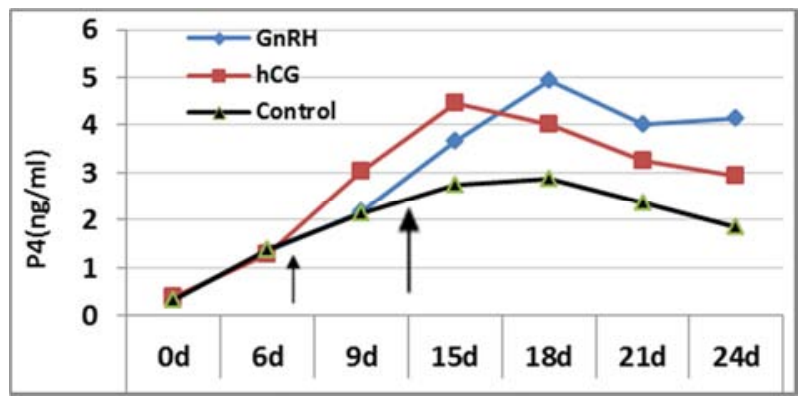

Figure 1. Change in P4 level of cows in the experimental groups on different post-mating days.

Several authors recommended that the main objective of GnRH or hCG administration is to improve the fertility of post-partum by increasing P4 concentration [62, 69, 54, 34]. The maintenance of pregnancy is due either to the maternal recognition of pregnancy and to the embryo capability of blocking luteolysis since day 16 post-AI [36]. This process occurs by the production of bovine trophoblastic protein-1 (bTP-1), also called IFN $\tau$ [55]. This protein can avoid CL regression by inhibiting the development of oxytocin receptors on the endometrium [57], or by activating a prostaglandin inhibitor [72]. Impaired P4 secretion has been linked with a reduced capacity of the developing embryo to secrete IFN $\tau$ at threshold amounts necessary to prevent luteolysis [73].

The hormonal treatments to increase P4 early in pregnancy were proven successful in increasing PR in cattle [34]. In our study, P4 level elevated on day 9 in buffaloes treated with hCG on day 7, and in those treated with GnRH on day 12, but $\mathrm{P} 4$ concentrations in both treatment groups were significantly different to controls only on day 15 . Despite many authors suggested that GnRH and hCG may stimulate increased P4 secretion from the existing CL [12, 47] explained inducing accessory $\mathrm{CL}$ formation through the administration of GnRH or hCG post-AI (day 4-7) leading to an increase in circulating P4 levels, the ultrasonographic examination cleared no accessory CL were found in treatment groups. Therefore, the hormonal treatment with GnRH or hCG may affect the average diameter of CL. [47] reported that plasma $\mathrm{P} 4$ concentration has been reported to increase significantly $(\mathrm{p}<0.05)$ in pregnant animals treated with GnRH and HCG on day $5^{\text {th }}$ post-mating than the control pregnant animals on day 15 and 20.

Although P4 peak was on day 18 post-mating in $\mathrm{GnRH}$ and control group, the injection of GnRH on day 12 postmating, higher P4 peak in GnRH than in control group was in association with increasing PR and reducing the incidence of embryonic mortality (EM) in GnRH compared with hCG. On the other hand, the earlier and lower P4 peak in hCG than in GnRH showed a less positive effect of hCG treatment on PR and EM. It is, therefore, possible that P4 was not elevated for a sufficient time in the period after AI to have a major effect on uterine function and embryo maternal interactions [11].

The present study indicated that P4 level pronouncedly increased in GnRH group in comparing with the control starting on day 15 post-mating and thereafter. In this respect, [6] concluded that administration of $\mathrm{GnRH}$ on day 23 increased plasma P4 in lactating Nili-Ravi buffaloes. Similar to buffalo-cows treated with GnRH in our study, [46] showed that GnRH administered 12 days post insemination significantly increased serum $\mathrm{P} 4$ on day 18 post-insemination in dairy cattle. Also, administration of GnRH injection in cows at 11-13 day post-AI have been reported to cause ovulation of second follicular wave follicle, induce accessory CL formation, stimulate CL function, induce increase plasma $\mathrm{P} 4$, reduce estrogen production and have a positive effect on embryo survival and ultimately improving fertility responses [45].

In accordance with the present trend of increase in P4 level on day 9 compared with the control in hCG group, In buffaloes, [12] observed that P4 increased on day 10 after injection of $1.500 \mathrm{I}$. U. of hCG. They suggested that hCG can induce ovulation and formation of an accessory corpus luteum which leads to increased P4 sometime later. In bovine, hCG has been used with variable success to ovulate dominant follicle and accessory CL formation [32]. Injection of hCG increased plasma P4 by $5 \mathrm{ng} / \mathrm{mL}$ compared to saline injection. Treatment with hCG on the day the $5^{\text {th }}$ day of oestrous synchronization has been reported to induce accessory CLs formation in $86.2 \%$ of cows, compared to $23.2 \%$ in controls 
[62]. In cattle, hCG treatment on day 5 or 7 post-AI increased P4 level by enhancing secretion from the existing CL and induction of ovulation for accessory CL formation [29, 62].

\subsection{Average CL Diameter on Different Post-mating Days}

Effect of treatment on average CL diameter on different post-mating days (Table 3) showed a slight increase in P4 level in hCG than in other groups on day 9 post-mating, but the differences were not significant. This increase was in association with hCG injection on day 7 post-mating, and no treatment in GnRH and control groups 9 days post-mating. On day 15 and 18 post-mating, CL diameter was significantly $(\mathrm{P}<0.05)$ higher in $\mathrm{GnRH}$ and $\mathrm{hCG}$ than in control (Figure 2), which may indicate more impact of both hormonal treatments on $\mathrm{CL}$ diameter. It is worth noting that improving CL diameter was more efficient by GnRH than hCG, because GnRH increased CL diameter tin nearly similarity with hCG on day 18 post-mating within 6 days versus 11 days in hCG group.

Table 3. The average diameter of corpus luteum in experimental groups on different post-mating days

\begin{tabular}{llll}
\hline \multirow{2}{*}{ Post-mating Day } & \multicolumn{2}{l}{ Experimental group } & G3 (control \\
\cline { 2 - 4 } & G1 (GnRH) & G2 (hCG) & $5.128 \pm 0.245$ \\
9 & $5.528 \pm 0.448$ & $6.042 \pm 0.420$ & $5.871 \pm 0.338^{\mathrm{b}}$ \\
15 & $7.757 \pm 0.979^{\mathrm{a}}$ & $8.342 \pm 0.515^{\mathrm{a}}$ & $6.614 \pm 0.376^{\mathrm{b}}$ \\
18 & $10.985 \pm 1.752^{\mathrm{a}}$ & $10.6714 \pm 1.26^{\mathrm{a}}$ & $0.37190^{\mathrm{NS}}$ \\
\hline
\end{tabular}

${ }^{\mathrm{a} \text { and }}$ : Means denoted within the same row with different superscripts are significantly different at $\mathrm{P}<0.05$. ${ }^{*} \mathrm{CC}$ : Correlation coefficient between $\mathrm{CL}$ diameter and P4 level. ${ }^{\text {NS: }}$ Not significant. ${ }^{* * *}$ Significant at $\mathrm{P}<0.001$.

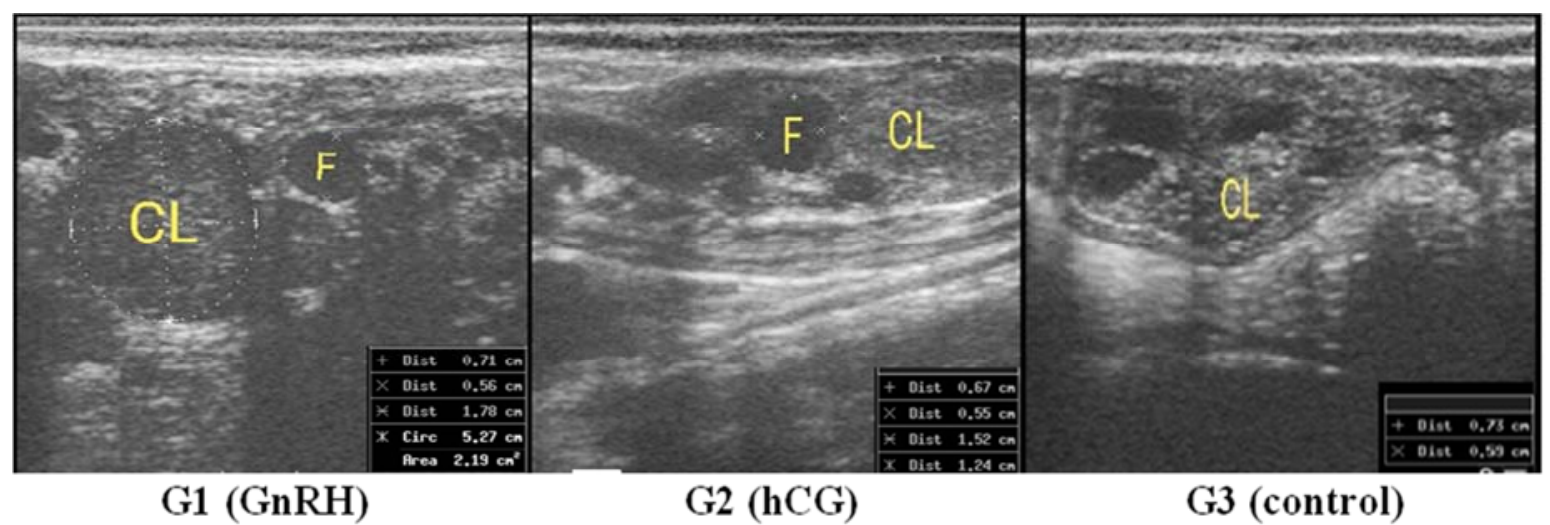

Figure 2. Ultrasonographic image showing follicle $(F)$ and $C L$ with average diameter of 1.78, 1.38 , and $0.66 \mathrm{~cm}$ in $\mathrm{G} 1$, G2, and G3 on day 18 post-mating, respectively.

[35] Showed P4 level is related to the diameter of the CL that secretes $\mathrm{P} 4$ until it reaches its final size. The present study indicated an association between CL diameter and P4 in each group on days 9,15 and 18 post-mating days, but the significant correlation between them was recorded only in GnRH group. A significant correlation $(\mathrm{r}=0.89, \mathrm{p}<0.001)$ was found between P4 level and total CL area [69]. Similarly administration of GnRH injection at 11-13 day post-AI has been reported to stimulate $\mathrm{CL}$ function, induce increase plasma $\mathrm{P} 4$, reduce estrogen production and have a positive effect on embryo survival and ultimately improving fertility responses [45]. Also, in cattle, hCG treatment on day 5 or 7 post-AI increased $\mathrm{P} 4$ level by enhancing $\mathrm{P} 4$ secretion from the existing CL [29, 62]. Contrary, total and principle CL areas were significantly higher on days 20 and 23 in hCGtreated cows compared to GnRH and control groups [10]. Also, the present finding is contrasted by the observation of an increase of CL area in hCG- treated cows compared with GnRH-treated cows with a strong positive and close correlation between the total luteal area and P4 level in GnRH group and previous studies [24].

\subsection{Serum P4 Profile in Pregnant and Non-pregnant at Each Sampling Time Post-mating}

In cattle, pregnancy was diagnosed when P4 concentrations in serum were above $1.6 \mathrm{ng} / \mathrm{ml} 24$ days postmating [76]. In our study, pregnant animals were confirmed by the ultrasonographic examination (Figure 3) on day 27 post-mating, and these cases were insured by $\mathrm{P} 4$ concentration.

Data illustrated in figure 4 showed that serum P4 level showed a marked increase by advancing post-mating day up to day 18 post-mating, but $\mathrm{P} 4$ concentration was higher in pregnant than in non-pregnant animals, regardless of treatment. Thereafter, P4 level increase in pregnant and decreased in non-pregnant up to $24 \mathrm{~d}$ post-mating but the significant differences between pregnant and non-pregnant animals started on day 9 post-mating.

The concentration of serum $\mathrm{P} 4$ in pregnant buffaloes averaged $\geq 5 \mathrm{ng} / \mathrm{ml}$ versus $<1 \mathrm{ng} / \mathrm{ml}$ in non-pregnant animals (Figure 4). Exposure to insufficient concentrations of P4 during the growth of the ovulatory follicle is one of the 
important factors that affect fertility in high producing animals [75]. Fertility reduction in cattle owing to insufficient maternal luteal function and the P4 dependent favorable uterine environment was reported by [5].

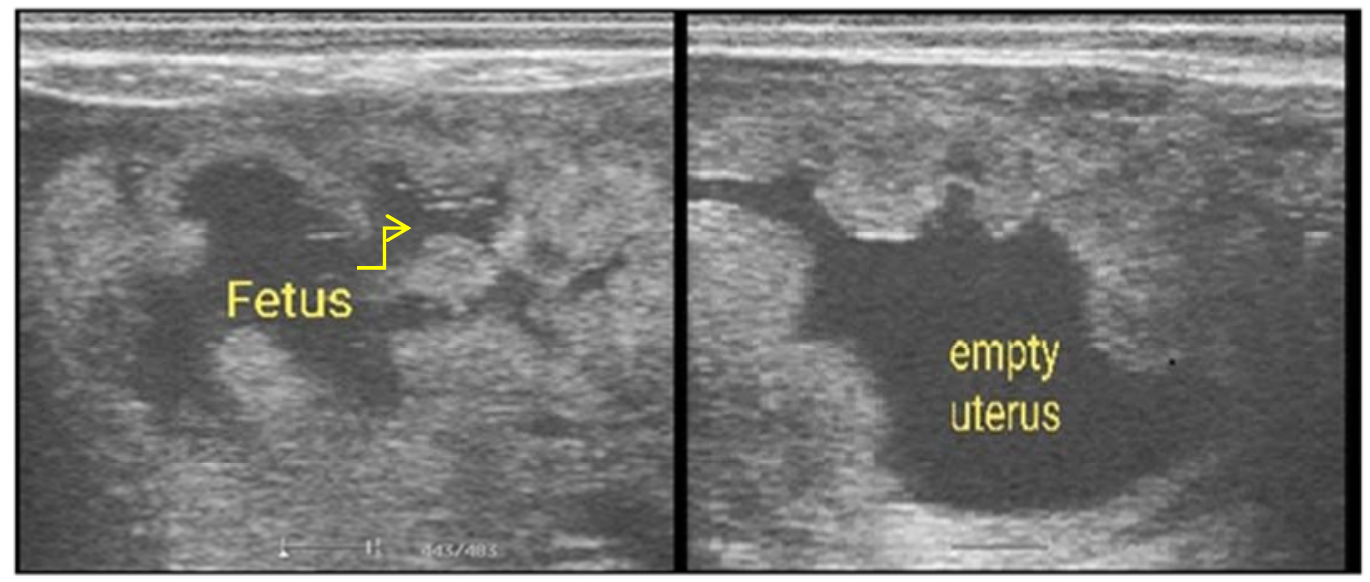

Pregnant

Non-pregnant

Figure 3. Ultrasonographic image showing pregnancy diagnosis in pregnant (fetus) and non-pregnant (empty uterus) buffaloes on day 27 post-mating.

In accordance with the present results, [13] found higher P4 plasma levels in pregnant buffaloes than in buffaloes which showed embryonic mortality since day 10 after AI, whilst P4 in non-pregnant buffaloes was intermediate. Plasma P4 concentration significantly decreased only in nonpregnant buffaloes between day 10 and 20. Pregnant buffaloes had also higher plasma P4 on day 20 than both non-pregnant buffaloes and those with embryonic mortality incidence. The same trend was observed by [14], who observed higher concentrations of $\mathrm{P} 4$ milk whey in pregnant buffaloes showed than both animals showing embryonic mortality and non-pregnant buffaloes on day 20 and day 25 but only than non-pregnant buffaloes on day 10 post-mating.

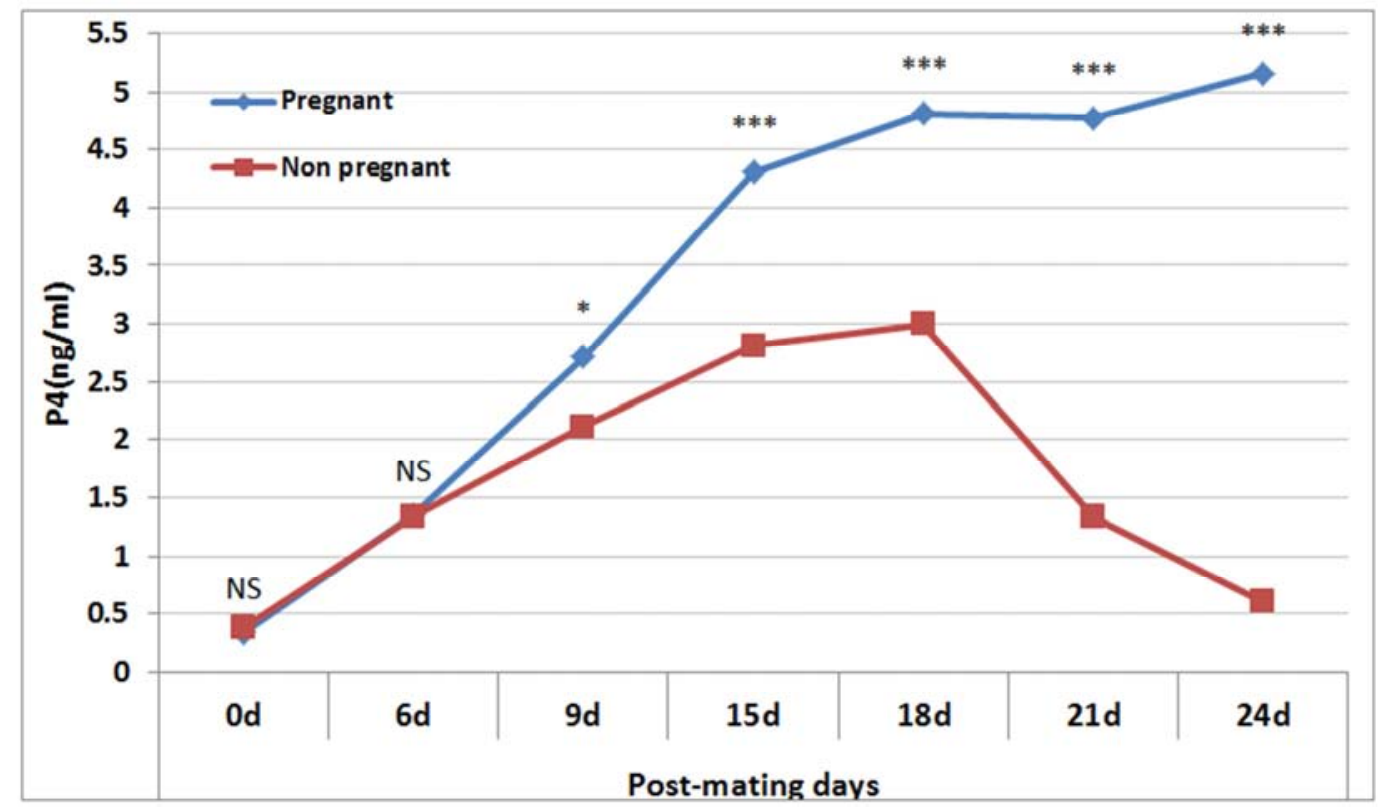

Figure 4. Progesterone (P4) concentration (ng/ml) in pregnant and non-pregnant buffalo cows. ${ }^{\text {NS }}$ Not significant. * Significant difference at P<0.05. *** Significant difference at $P<0.001$.

Concerning serum P4 concentration on different postmating days within each treatment results illustrated in figure 5 cleared increasing $\mathrm{P} 4$ concentration in pregnant than in non-pregnant animals within each treatment. From 0 to 18 day post-mating, P4 level showed a similar trend in pregnant or non-pregnant within each treatment, being the highest in pregnant of hCG, and the lowest in non-pregnants of the control group. However, the differences in P4 concentration between pregnant and non-pregnant within each treatment, and even between pregnants in each treatment were more obvious from 18 to 24-day post-mating. During this interval, P4 concentration was significantly $(\mathrm{P}<0.05)$ higher in pregnant than in non-pregnant within each treatment, being significantly $(\mathrm{P}<0.05)$ the highest in pregnant of $\mathrm{GnRH}$ 
treatment, followed by hCG, and the lowest in control.

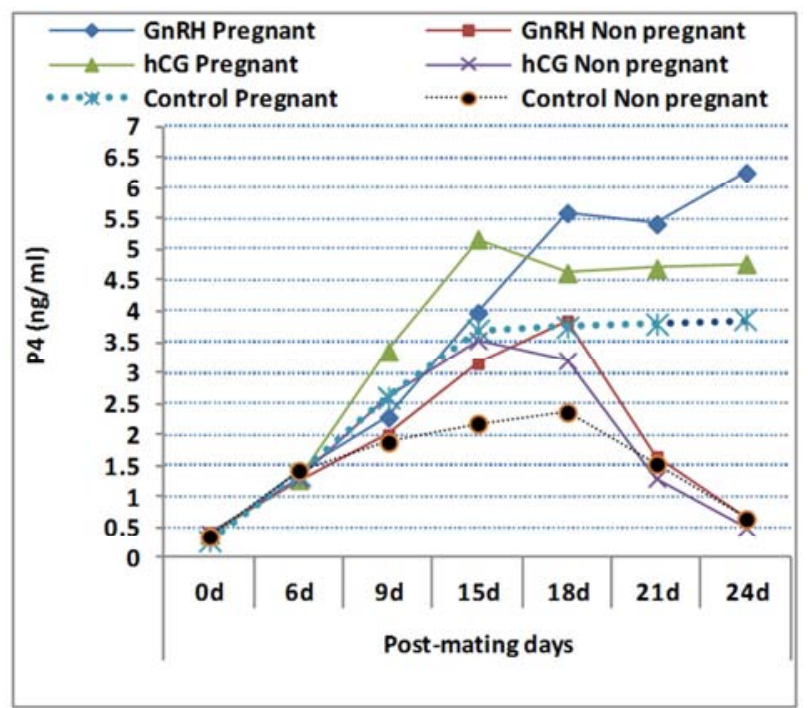

Figure 5. Progesterone (P4) concentration ( $\mathrm{ng} / \mathrm{ml})$ in pregnant and nonpregnant of buffalo cows of the experimental groups.

The observed highest P4 concentration in GnRH group indicated that ovulatory response to $\mathrm{GnRH}$ treatment causing a progressive increase in $\mathrm{P} 4$ concentrations during most postmating days. This is in agreement with [12], who observed an increase in why milk P4 level of buffaloes on days 15 and 20, while progesterone levels remained relatively constant for buffaloes that did not ovulate.

In cattle, the differences in mean $\mathrm{P} 4$ concentrations on day 12 to 24 post-mating in pregnant cows of the control group and GnRH treatment were non-significant [76]. In the present study, P4 concentration in pregnants was significantly $(\mathrm{P}<0.05)$ higher in $\mathrm{GnRH}$ than in the control group. This may indicate that the chances of pregnancy loss in animals with high circulating levels of progesterone are significantly reduced [75].

The underlying mechanism by which P4 modulates fertility likely involves a change in the pattern of LH release [19]. During pregnancy, the embryo produces a protein, interferon tau, which acts locally within the uterus to inhibit PGF $2 \alpha$ secretion. This interferon tau protein is first detected in significant quantities in uterine flushes between days $14-16$ when embryos have begun elongation [56]. In cattle, interferon-tau extends the lifespan of the corpus luteum by suppressing estradiol receptor and oxytocin receptor genes [65] and by attenuating the endometrial secretion of PGF2 $\alpha$ [23]. It has also been shown that interferon-tau reduces PGF $2 \alpha$ secretion by bovine endometrial explants [22] and endometrial epithelial cells [16]. Therefore, it is believed that the prolonged release of GnRH induces LH surge of longer duration and thereby it subsequently uses to stimulate CL growth and function ultimately improving fertility responses [3].

\section{Conclusion}

Early embryonic mortality was associated with reduced circulating concentrations of $\mathrm{P} 4$. The injection of $5 \mathrm{ml}$ receptal $(\mathrm{GnRH})$ on day 12 post-mating increased corpus luteum function, $\mathrm{P} 4$ production, pregnancy rate, and farmer economy of lactating Egyptian buffaloes, in comparing with the injection with hCG (1500 IU/animal) on day 7 postmating and those in the control group. Treatment with $\mathrm{GnRH}$ may reduce the early embryonic loss by increasing diameter of corpus luteum to increase P4 level in repeat breeder buffaloes during early post-mating period.

\section{Recommendations}

To reduce the embryonic loss during the early interval of pregnancy and increase pregnancy rate in buffaloes, reproductive problems of repeat breeding in buffaloes could be solve by hormonal treatment, especially with GnRH on day 12 post-mating. From the economical point of view, this treatment can encourage buffalo breeders to increase their benefits.

Further studies are required for improving reproductive efficiency of repeat breeder buffalos by using other protocols with different levels and types of hormones.

\section{References}

[1] Abo-Farw, M. A. and Ghoneim M. M. (2017). Effect Of GnRH Administration At Mating And During Luteal Phase On Pregnancy Rate Of Repeat Breeder Buffalo Cows. Veterinary Medical Journal - Giza (VMJG) 63 (1) - 65-74.

[2] Abo-Farw, M. A, El-Ratel I. T, Abdel-Khalek A. E, Abouelghet H. A. and Ghoneim M. M. (2016). Effect of $\mathrm{GnRH}$ treatment during different times post-mating on pregnancy rate of buffalo heifers. Egyptian J. Anim. Prod. 53 (2): 59-64.

[3] Ambrose, J. D, Pires M. F. A, Moreira F, Diaz T, Binelli M. and Thatcher W. W. (1998). Influence of Deslorelin (G\&Hagonist) implant on plasma progesterone, first wave dominant follicle and pregnancy in dairy cattle. Theriogenology 50: 1157-1170.

[4] Anjum, I. A, Usmani R. H, Tunio M. T. and Abro S. H. (2009) Improvement of conception rate in crossbred cattle by using GnRH analogue therapy. Pakistan Vet. J, 29 (2): 93-94.

[5] Arndt, W. J, Holle A. J, Bauer M. L, Kirsch J. D, Schimek D. E, Oddeand K. G. and Vonnahme, K. A. (2009). Effect of post-insemination progesterone supplementation on pregnancy rate in dairy cows. Cand. J. of Vet. Res. 73 (4), 271-74.

[6] Arshad, U, Tahir M. Z, Yousuf M. R, Shahzad M. and Ahmad N. (2018). Administration of GnRH on day 23 post AI enhances plasma progesterone, embryonic survival, and herd fertility in lactating Nili-Ravi buffaloes. Reproduction in Domestic Animals Vol. 53 Supplement 2.

[7] Bajaj, N. K. (2001). Effect of herbal medication on endometritis in buffaloes. M. Sc. Thesis, Gujarat. Agricultural University, Anand Campus, S. K. Nagar (Gujarat). India.

[8] Bajaj, N. K, Panchal M. T, Kalyani L. H. and Kavani F. S. (2006). bacterial isolates and antibiotic sensitivity spectrum of Cervico-vaginal mucus of endometritic buffaloes. JNKVV Res. J, 40: 91-95. 
[9] Bartolome, J. A, Melendez P, Kelbert D, Swift K, McHale J, Hernandez J, Silvestre F, Risco C. A, Arteche A. C. M, Thatcher W. W, Archibald L. F. (2005). Strategic use of gonadotrophin-releasing hormone $(\mathrm{GnRH})$ to increase pregnancy rate and reduce pregnancy loss in lactating dairy cows subjected to synchronization of ovulation and timed insemination. Theriogenology. 63: 1026-1037.

[10] Besbaci, M, Abdelli A, Belabdi I, Benabdelaziz A, Khelili R, Mebarki M, Kaidi R. (2018). Effects of GnRH or hCG on day 11 after artificial insemination in cows luteal activity. J Hellenic Vet Med Soc, 69 (4): 1227-1234.

[11] Campanile, G, Di Palo R, Neglia G, Vecchio D, Gasparrini B, Prandi A, Galiero G, and D'Occhio M. J. (2007a). Corpus luteum function and embryonic mortality in buffaloes treated with a GnRH agonist, hCG and progesterone. Theriogenology 63: pp. 2334-2340.

[12] Campanile, G, Neglia G. (2007). Embryonic mortality in buffalo cows. Ital. J. Anim. Sci. vol. 6, (Suppl. 2), 119-129, 2007.

[13] Campanile, G, Neglia G, Gasparrini B, Galiero G, Prandi A, Di Palo R, D'Occhio M. J. and Zicarelli L. (2005). Embryonic mortality in buffaloes synchronized and mated by AI during the seasonal decline in reproductive function. Theriogenology 63: pp. 2334-2340. Theriogenology 52: pp. 573-583.

[14] Campanile, G, Vecchio D, Neglia G, Di Palo R, Prandi A, D'Occhio M. J. (2007b). Progesterone and pregnancy status in buffaloes treated with a GnRH agonist. Livestock Science, in press. Theriogenology; 67: pp. 1393-1398.

[15] Dadarwal, D, Mapletoft R. J, Adams G. P, Creelman C. and Singh J. (2013.) Effect of progesterone concentration and duration of proestrus on fertility in beef cattle after fixed-time artificial insemination. Theriogenology. 79: 859-66.

[16] Danet-Desnoyers, G, Wetzels C. and Thatcher W. W. (1994). Natural and recombinant bovine interferon 7 regulate basal and oxytocin- induced secretion of prostaglandins $\mathrm{F} h$ and $\&$ by epithelial cells and stromal cells in the endometrium. Reprod. Fertil. Dev. 6: 193-202.

[17] Dimitrov M, Vassilev N, Georgiev P, Ivanov I, Yotov S. (2002). Ultrasonographic assessment of early pregnancy in animals. Bulgarian J. Vet. Medicine, 5, № 3, 167-178.

[18] Duncan, D. B. (1955). Multiple range and Multiple F test. Biometrics, 11: 10

[19] Endo, N, Nagai K, Tanaka T. and Kamomae H. (2012). Comparison between lactating and non-lactating dairy cows on follicular growth and corpus luteum development, and endocrine patterns of ovarian steroids and luteinizing hormone in the estrous cycles. Animal Reproduction Science 134 112118.

[20] Ganaie, B. A, Sheikh A. A, Sultan F, Bhat S, Lone S. and Malik T. (2017). Strategies to Manipulate Progesterone For Improved Ovarian and Fertility Responses in Bovines - A Review. International Journal of Livestock Research, 7 (12), $1-12$.

[21] Gumen, A, Keskin A, Yilmazbas-Mecitoglu G, Karakaya E, Cevik S. and Balci F. (2011). Effects of GnRH, PGF2alpha and oxytocin treatments on conception rate at the time of artificial insemination in lactating dairy cows. Czech J. Anim. Sci, 6, 279-283.
[22] Helmer, S. D, Gross T. S, Newton G. R, Hansen P. J. and Thatcher, W. W. (1989b). Bovine trophoblast protein-I complex alters endometrial protein and prostaglandin secretion and induces an intracellular inhibitor of prostaglandin synthesis in vitro. J. Reprod. Fertil. 87: 421430 .

[23] Helmer, S. D, Hansen P. J, Thatcher W. W, Johnson J. W. and Bazer F. W. (1989a). Intrauterine infusion of highly enriched bovine trophoblast protein-1 complex exerts an antiluteolytic effect to extend corpus luteum lifespan in cyclic cattle. J. Reprod. Fertil. 87: 89-101.

[24] Herzogn, K, Brockhan-Ludemann M, Kaske M, Beindorff N, Paul V, Niemann H. and Bollwein H. (2010). Luteal blood flow is a more appropriate indicator for luteal function during the bovine estrous cycle than luteal size. Theriogenology 73 691-697.

[25] Humblot, P. (2001). Use of pregnancy specific proteins and progesterone assays to monitor pregnancy and determine the timing, frequencies and sources of embryonic mortality in ruminants. Theriogenology, 56: 1417-1433.

[26] Jainudeen, M. R, Hefez E. S. S. (2000). Gestation, prenatal physiology, and parturition. In: Reproduction in Farm Animals Hafez B. and Hafez E. S. E. (Eds.). 7th ed. Lipponcott Williams. Wilkins. USA. Pp. 147.

[27] Kastelic, J. P. (1994). Non-infectious embryonic loss in cattle. Vet. Med. 89 (6), 584-589.

[28] Kastelic, J. P, Northey D. L. and Ginther O. J. (1991). Spontaneous embryonic death on days 20 to 40 in heifers. Theriogenology, 35: 351-363.

[29] Kerbler, T. L, Buhr M. M, Jordan L. T, Leslie K. E. and Walton J. S. (1997). Relationship between maternal plasma progesterone concentration and interferon-tau synthesis by the conceptus in cattle. Theriogenology. 47: 703-714.

[30] Kharche, S. D. and Srivastava S. K. (2007). Dose dependent effect of GnRH analogue on pregnancy rate of repeat breeder crossbred cows. Anim. Reprod. Sci, 99, 196.

[31] Kumar, S. and Purohit G. N. (2017). Effect of different hormonal therapies on day 5 of estrous on plasma progesterone profile and conception rates in repeat breeding dairy cows. J. Anim. Health Prod, 5 (3), 103-106.

[32] Lonergan, P. (2011). Influence of progesterone on oocyte quality and embryo development in cows. Theriogenology. 76: 1594-1601.

[33] Lucy, M. C. (2001). Reproductive loss in high-producing dairy cattle: Where will it end? J. Dairy Sci. 84: 1277-2193.

[34] Maillo, V, Duffy P, O'Hara L, De Frutos C, Kelly A. K, Lonergan P, Rizos D. (2014). Effect of hCG administration during corpus luteum establishment on subsequent corpus luteum development and circulating progesterone concentrations in beef heifers. Reprod Fertil Dev 26: 367-374.

[35] Mann, G. E. (2009) Corpus luteum size and plasma progesterone concentration in cows. Animal Reproduction Science 115 296-299.

[36] Mann, G. E. and Lamming G. E. (1999). The influence of progesterone during early pregnancy in cattle. Reproduction in Domestic Animals 34, 269-274. 
[37] Mann, G. E. and Lamming G. E. (2001). Relationship between the maternal endocrine environment, early embryo development and the inhibition of the luteolytic mechanism in the cow. Reproduction 121, 175-180.

[38] Mann, G. E, Lamming G. E, Robinson R. S. and Wathes D. C. (1999). The regulation of interferon-tau production and uterine hormone receptors during early pregnancy. Journal of Reproduction and Fertility Supplement 54: 317-328.

[39] Mann, G. E. (2002). Corpus luteum function and early embryonic death in the bovine. XXII World Buiatrics Congress, Hannover, pp. 300-306. Germany, August 18-23.

[40] Mathew, R, Aravinda M, Ghosh K. N, Kurien M. O. and Harshan H. M. (2013). Comparison of Human Placental Extract, hCG and GnRH Analogue on Fertility of Repeat breeding Cattle. Indian Vet. J, 90 (4), 57-59.

[41] Maurer, R. R. and Chenault J. R. (1983). Fertilization failure and embryonic mortality in parous and nonparous beef cattle. Journal of Animal Science, 56: 1186-1189.

[42] Mee, M. O, Stevenson J. S. and Scoby R. K. (1990). Influence of gonadotropin-releasing hormone and timing of insemination relative to estrous on pregnancy rates of dairycattle at first service. Journal of Dairy Sci, 73, 15001507.

[43] Mehrotra, S, Chaudhari R. K. and Narayanan K. (2015). Improvement of fertility usingbuserelin acetate in repeat breeding cattle. Ind. J. of Ani. Repro. 36 (1), 50-52.

[44] More, R. M, Patil A. D, Kumbhar U. B. and Mugale R. R. (2012). Fertility improvement by hormonal therapies in repeat breeding cows. Indian. J. Anim. Repro, 33 (2), 61-63.

[45] Musilova, D, Bartoněk J, Čech S, Páleník T. and Doležel R. (2014). Induction of accessory corpus luteum in cows by gonadotropin-releasing hormone administrated after insemination. ActaVeteranaria Brno. 83: 107-111.

[46] Nussara, V, Arun C, Wanvipa S. and Kriwon H. (2008). Progesterone profiles and conception of dairy cattle administered with gonadotropin releasing hormone in luteal phase post inseminations. Journal of Mahanakom Veterinary Medicine. Vol. 3 No. 1 January - June 2008.

[47] Pandey, N. K. J, Gupta H. P, Prasad S. and Sheetal S. K. (2016). Plasma progesterone profile and conception rate following exogenous supplementation of gonadotropinreleasing hormone, human chorionic gonadotropin, and progesterone releasing intra-vaginal device in repeat-breeder crossbred cows. Veterinary World. 9 (6): 559-562.

[48] Parikh, S. S, Makwana R. B, Savaliya B. D, Patbandha T. K. and Murthy K. S. (2018). Effect of Hormonal Therapy on Fertility in Repeat Breeding Gir Cows. International Journal of Current Microbiology and Applied Sciences. ISSN: 23197706 Special Issue-7 pp. 4952-4958. Journal homepage: http://www.ijcmas.com.

[49] Patel, J. A, Dhami A. J, Kavani F. S, Panchal M. T. and Ghodasara D. J. (2010). Therapeutic management and changes in the endometrium of repeat breeding cows. Indian. J. Anim. Repod, 31, 1 .

[50] Peters, A. R. (1996). Embryo mortality in the cow. Anim Breed Abst 64, 587-598.

[51] Peters, A. R, Martinez T. A. and Cook A. J. (2000). A meta- analysis of studies of the effect of GnRH 11-14 days after insemination on pregnancy rates in cattle. Theriogenology 54: 1317-126.

[52] Reddy, K. R. C, Reddy K. C. S. and Reddy V. C. S. (2001). Efficacy of Progesterone treatment in repeat breeding Ongole cattle. Indian Vet. Med. Jour, 25 (2), 193.

[53] Drew, S. B. and A. R. Peters (1992). The effect of treatment with a gonadotrophin -releasing hormone analogue on the fertility of dairy cows. Proc. Int. Congr. Anim. Rep, Hague, Netherlands, 3: 319 .

[54] Rizos, D, Scully S, Kelly A. K, Ealy A. D, Moros R, Duffy P, Naib A. I, Forde N. and Lonergan P. (2012). Effects of human chorionic gonadotrophin administration on Day 5 after oestrus on corpus luteum characteristics, circulating progesterone and conceptus elongation in cattle. Reprod Fertil Dev 24: 472-481.

[55] Roberts, R. M, Leaman D. W. and Cross J. C. (1992). Role of interferons in maternal recognition of pregnancy in ruminants. ProcSocExpBiol Med. 200 (1): 7-18.

[56] Robinson, R. S, Fray M. D, Wathes D. C, Lamming G. E. and Mann G. E. (2006). In vivo expression of interferon tau mRNA by the embryonic trophoblast and uterine concentrations of interferon tau protein during early pregnancy in the cow. Molecular Reproduction and Development 73, 470-474.

[57] Robinson, R. S, Mann G. E, Wathes D. C. and Lamming G. E. (1997). The effect of pregnancy on oxytocin and oestrogen receptor expression in the bovine uterus. J. Reprod. Fertil. Abstr. Ser. 19: 122.

[58] Roche, J. F, Boland M. P. and Mcgeady T. A. (1981). Reproductive wastage following artificial insemination of heifers. The Veterinary Record, 109: 401-404.

[59] Roy, G. P, Akhtar M. H, Singh A. P, Prasad K. M. and Singh R. B. (1995). Effect of Receptal to improve the fertility in bovines. Indian J. Anim. Repro, 16, 131.

[60] Ryan, D. P, Snijders S, Condon T, Grealy M, Sreenan J, O'Farrell K. J. (1994). Endocrine and ovarian responses and pregnancy rates in dairy cows following the administration of a gonadotrophin releasing hormone analogueat the time of artificial insemination or at mid-cycle post insemination. Anim. Reprod. Sci. 34, 179-191.

[61] Santos, J. E, Thatcher W. W, Chebel R. C, Cerri R. L, Galvao K. N. (2004). The effect of embryonic death rates in cattle on the efficacy of estrus synchronization programs. Anim Reprod Sci. 82/83: 513-35.

[62] Santos, J. E. P, Thatcher W. W, Pool L. and Overton M. W. (2001). Effect of human chorionic gonadotropin on luteal function and reproductive performance of high-producing lactating Holstein dairy cows Veterinary American Society of Animal Science. Journal of Animal Science. 79: 2881-2894.

[63] Senthilkumar, A, Balamurugan P, Sribalaji N, Srinivasan G. and Murugesan S. (2017). Hydroxy progesterone, human chorionic gonadotropin and $\mathrm{GnRH}$ analogue on fertility of repeat breeding dairy cattle in Theni district of Tamilnadu. Int. J. of Sci, Envi. And Tech, 6 (1), 734-737.

[64] Sharma, A, Jindal R, Singh N. and Singh R. V. (2003). Effect of progesterone supplementation on conception rate and hormonal profile in repeat breeding buffaloes. Indian J. Anim. Sci, 73 (7), 773-774. 
[65] Spencer, T. E. and Bazer F. W. (2004). Conceptus signals for establishment and maintenance of pregnancy. Reprod. Boil. Endoc, 5: 49-49.

[66] Sreenan, J. M, Diskin M. G. (1986). The extent and timing of embryonic mortality in the cow. In: JM Sreenan and MG Diskin (eds), Embryo Mortality in Farm Animals. Martinus Nijhoff, Dordrecht, pp 1-1 1.

[67] Sreenan, J. M, Diskin M. G. and Morris D. G. (2001). Embryo survival rate in cattle: a major limitation to the achievement of high fertility. Volume 26, Issue 1 (Fertility in the High Producing Dairy Cow). January 2001, pp. 93-104.

[68] Starbuck, M. J, Dailey R. A, Inskeep E. K. (2004). Factors affecting retention of early pregnancy in dairy cattle. AnimReprod Sci. 84: 27-39.

[69] Stevenson, J. S, Portaluppi M. A, Tenhouse D. E, Lloyd A, Eborn D. R, Kacuba S. and De Jarnette J. M. (2007). Interventions after artificial insemination: conception rates, pregnancy survival, and ovarian responses to gonadotrophinreleasing hormone, human chorionic gonadotrophin, and progesterone. J Dairy Sci 90: 331-340.

[70] Tanabe, T. Y, Deaver D. R. and Hawk H. W. (1994). Effect of gonadotropin-releasing hormone on estrus, ovulation, and ovum cleavage rates of dairy cows. J. Anim. Sci, 72 (3), 71924.

[71] Thatcher, W. W, Drost M, Savio J. D, Macmillan K. L, Entwistle K. W, Schmitt E. J, Soat R. L. and Morris G. R. (1993). New clinical uses of GnRH and its analogue in cattle. Anim. Repro. Sci, 33, 27-49.
[72] Thatcher, W. W, Meyer M. D, Danet-Desnoyers G. (1995). Maternal recognition of pregnancy. J. Reprod. Fertil. Suppl. 49: 15-28. Cattle.

[73] Wathes, D. C, Wathes R. S, Robinson G. E, Mann G. E. and Lamming (1998). The establishment of early pregnancy in cows Reprod. Domestic Animals, 33, pp. 179-284.

[74] Willard, S, Gandy S, Bowers S, Graves K, Elias A, Whisnant C. (2003). The effects of $\mathrm{GnRH}$ administration postinsemination on serum concentrations of progesterone and pregnancy rates in dairy cattle exposed to mild summer heat stres. Theriogenology, 59: 1799-1810.

[75] Wiltbank, M. C, Souza A. H, Giordano J. O, Nascimento A. B, Vasconcelos J. M, Pereira M. H. C, Fricke P. M, Sarjus R. S, Zinsly F. C. S, Carvalho P. D, Bender R. W. and Sartori R. (2012). Positive and negative effects of progesterone during timed AI protocols in lactating dairy cattle. Animal Reproduction. 9 (3): 231-241.

[76] Yildiz, H, Kaygusuzoğlu E, kaya M. and Çenesiz M. (2009). Effect of post-mating GnRH treatment on serum progesterone, luteinizing hormone levels, duration of estrous cycle and pregnancy rates in cows. Pakistan Vet. J, 2009, 29 (3): 110114.

[77] Zavy, M. T. (1994). Embryonic mortality. In: M. T. Zavy and R. D. Geisert (ed.) Embryonic Mortality in Domestic Species. pp 99-140. CRC Press, Boca Raton, FL. 